\title{
Doing good by doing well? Microfinance, Self-regulation and borrowers' overindebtedness in the Dominican Republic
}

\author{
Joana Silva Afonso $^{1}$, Solène Morvant-Roux ${ }^{2}$, Isabelle Guérin ${ }^{3}$ and Davide Forcella ${ }^{4}$ \\ ${ }^{1}$ University of Portsmouth, Hampshire, UK \\ ${ }^{2}$ University of Geneva, Geneva, Switzerland \\ ${ }^{3}$ Institute of Research for Development (IRD), Marseille, France \\ ${ }^{4}$ Université Libre Bruxelles and CERMi, Brussells, Belgium
}

Key Words: microfinance, overindebtedness prevention, financial practices, self-regulation, Dominican Republic

Acknowledgments: The authors wish to acknowledge the contributions of all the partners in the Dominican Republic, namely the managers and staff of the microfinance institutions (MFIs) involved in the study. The authors also wish to thank the European Investment Bank for funding the Microfinance in Crisis project, making this research possible, and the reviewers for their valuable comments. Finally, a special thanks is due to the interviewees who willingly gave their time and shared their experiences. 


\begin{abstract}
:
The Dominican Republic's microfinance sector is considered to be a solid market where overindebtedness prevention best practices are widely, and successfully, implemented. Relying on qualitative data collection tools and analysis, we identify these 'best practices' as selfregulation mechanisms, and we show how they fail to fully fulfil their goals in the Dominican market. While financial exclusion supports the idea of a sizeable microcredit market, we argue that the focus on growth and high competition strongly jeopardize the positive social outcomes of microcredit, and that only a paradigm shift within the sector will change the present situation.
\end{abstract}

\title{
1. Introduction
}

The promotion of poor people's financial inclusion has been one of the main pillars of development strategies around the world in the last 40 years. The communication of success of some organizations delivered the image of microfinance as the long awaited silver bullet able to end poverty: provide a credit to an unbanked person and she will escape from poverty by herself thanks to her own entrepreneurial spirit. At the same time, the institution that offers the credit must be profitable to ensure sustainability and to universalise financial inclusion (Soederberg, 2013).

This image of a win-win solution to poverty eradication, and a sizeable market, ${ }^{1}$ led to a commercialization trend and attracted new players into the field (Ledgerwood and Gibson, 2013; Intellecap, 2009). The new microfinance actors carried with them a banking logic that gradually gained space in the sector, replacing poverty alleviation as the main source of legitimacy driving the support from public and private donors. This paradigm shift came together with financial metrics becoming the 'universally' accepted performance measures, conditioning in this way the priorities of the MFIs (Kent and Dacin, 2013). The conceptualisation of poverty as a lack of goods and services dominated the international scene, and the discussion of complex structural, correlated and systemic factors supporting inequalities and generating poverty traps was avoided or not considered. "Capitalist structures, processes and beliefs remain at the core of these development 'solutions'" (Blowfield and Dowlan cited by Banks and Hulme 2014: 188).

In practice, the steady growth of microcredit schemes (in terms of number of branches and clients), along with market concentration, brought about strong competition and market saturation, at least in urban and peri-urban areas, and for the upper segment of the poorest. As the sector grew, in many of these areas, what was a credit demand gap became a credit oversupply with competition (among other factors) having a strong impact on the way the programs were being implemented and their outcomes (Chen et al., 2010; Assefa et al., 2013; McIntosh and Widyck, 2005).

\footnotetext{
${ }^{1}$ This significant unmet demand was for example portrayed in the 2009 report on the Indian microfinance market (Intellecap, 2009), and is reflected on the prediction made by ResponsAbility of a growth between $15 \%$ and $20 \%$ in 2015 for the global microfinance market (ResponsAbility, 2014).
} 
The delinquency crises faced by important microfinance markets, such as Bosnia-Herzegovina, Morocco, Nicaragua or Andhra Pradesh (Guérin et al., 2015; Rozas, 2013; Schicks, 2013), have drawn attention to the impact of microfinance on clients and, concurrently, the academic debate provided evidence supporting the lack of impact of the microcredit programs on poverty reduction (Banerjee et. al, 2015; Duvendack et al., 2011). ${ }^{2}$ Moreover, the research developed by J. Schicks in Ghana, focusing on repayment behavior from a client protection perspective, showed that clients may be over indebted and facing 'unacceptable' sacrifices, even if they manage not to default in their microfinance loans (Schicks, 2014; 2013). Overindebtedness has, thus, become a central issue in the sector, being identified as the top risk for the industry in the last two Banana Skin Reports (Lascelles and Mendelson, 2012; Lascelles et al., 2014).

The reaction to the crises has generated a number of initiatives, both at local and international levels, mostly based on self-regulation mechanisms implemented at the level of the microfinance institutions. The most relevant initiatives at international level include the Smart Campaign, the Universal Standards for Social Performance Management and Microfinance Transparency (International Finance Corporation, 2013). ${ }^{3}$

At national level, the Indian case is emblematic and illustrates the challenges of self-regulation (Forster, 2012). In January 2010, the then recently formed Microfinance Indian Microfinance Network (MFIN) tried to establish a Code of Conduct for its members. Driven by what were considered "isolated incidents of over-lending in some pockets of the country" (Intellecap, 2009: 7), the prevention of client overindebtedness was one of the issues included in the document. This initiative, however, did not enable to prevent the Andhra Pradesh crisis as competition, growth imperatives, and the lack of enforcement mechanisms constrained the implementation of the Code (Rozas, 2014).

When crises are seen as a sequence of "unique events that dislocate, rearticulate, and transform the interpretation and meaning of cultural symbols and social and economic structures", ${ }^{4}$ they may represent an opportunity for rupture and structural change (Thornton and Ocasio, 2008:116; Sewell, 1996). Notwithstanding, the response to the microfinance crisis, as for the major financial crisis, was not able to question the structure of the system itself, namely a competitive market aimed at meeting a hypothetical massive demand.

Actually, the self-regulation initiatives focused on procedural mechanisms, such as the use of both formal (including credit bureaus) and informal sources of information in the screening process; adequate training and incentive schemes to the staff; and respectful and adequate recovery procedures (Schicks and Rosenberg, 2011; Smart Campaign, 2013). Hence, client

\footnotetext{
${ }^{2}$ Six randomized control studies conducted between 2003 and 2012 highlight that no impact was found for poverty reduction variables, such as the total household income. These studies showed, however, that for an average borrower there were improvements in several indicators related to the business (revenues, profits, assets), and changes in the household income composition, with an increase of business income suggesting positive effects on consumption smoothing (Banerjee et al., 2015)

${ }^{3}$ The Smart Campaign was launched in 2009. It aims to raise awareness among practitioners for the need to focus on clients' well-being as the driving force of the industry, and to respect the principle of (at least) doing no harm to the clients (IFC, 2013).

${ }^{4}$ Especially when these crises are characterized by strong emotions and collective actions of the participants (Thornton and Ocasio, 2008), like it happened in Andhra Pradesh and Nicaragua.
} 
overindebtedness and market saturation have been seen as simple distortions of the credit industry that can be solved or fixed by the system itself.

Relying on field grounded research in the Dominican Republic, we argue that the issue of overindebtedness implies a deeper analysis. Even when seriously designed, and with wellintentioned purposes, self-regulation mechanisms may not be enough to protect microfinance consumers against overindebtedness, challenging the 'doing good by doing well' approach that lays down the commercialization paradigm of microfinance.

We use the case of the Dominican Republic to illustrate the dynamics underlying competitive microfinance markets that influence the application of procedures by the MFIs (particularly by the loan officers), and in turn the outcomes of the self-regulation mechanisms implemented to prevent overindebtedness. The implementation of such consumer protection mechanisms, presented as allying with the social principle of microfinance "not to harm the poor", reduces the default risk (i.e. in line with a market-led banking approach), but seems to fail to safeguard the debtors. The explanatory factors include the specificities of the context: a large informal lending sector, together with limited market potential, conflicts with high growth objectives, and translates into strong competition on a specific population segment (urban working poor).

We build our arguments on different sources with a combination of primary and secondary data, namely, field research conducted by the authors between 2012 and $2015^{5}$; data on the country's economic and social environment as well as its financial and microfinance markets published by the Dominican Republic Central Bank, REDOMIF and FondoMicro; and data on financial inclusion from the Global Findex Database.

The paper starts with a theoretical conceptualization of the self-regulation mechanisms used to prevent overindebtedness, and the market dynamics in which they are designed and implemented. In the following section, we present the methodological approach and give an overview of the Dominican Republic microfinance market. Section 4 analyses the self-regulation mechanisms applied by the main MFIs with reference to the overindebtedness prevention best practices, identifying insufficiencies and loopholes resulting from market dynamics associated with high competition contexts. The last section presents the conclusions.

\section{Microfinance markets and overindebtedness prevention}

Access to formal financial services is seen as essential to poor people that have to cope with low and irregular incomes, often with no help from supporting social and financial structures (as they are non-existent or deficient in developing countries), making these populations vulnerable to all sort of shocks, including unemployment, health emergencies and natural disasters (Collins et al., 2009).

While early microcredit schemes were designed to finance the income-generating activities of the unbanked and the poor populations, an alternative vision of microfinance has gained ground since the 2000s. It makes the case for boosting the financial inclusion of poor people through appropriate financial services, covering shortfalls in all areas of life, including consumer

\footnotetext{
${ }^{5}$ These research activities were conducted in the frame of the Microfinance in Crisis Project (www.microfinance-incrisis.org) funded by the European Investment Bank research program (EIBURS)
} 
expenditure, housing expenses, and basic services related expenses (Collins et al., 2009; Intellecap, 2009). This paradigm shift that occurred after 2005 opened new market opportunities for microcredit suppliers, entailing strong growth and competition between a diversity of providers, especially in urban and peri-urban areas. Therefore, the microfinance landscape has become more and more diversified, and competitive. Actually, beyond microfinance institutions, public programs and commercial banks willing to downscale their activities to low-income populations have also been working with microfinance clients (Ledgerwood and Gibson, 2013).

Competition among suppliers is theoretically seen as positive for the clients by lowering prices and encouraging the development of new products. This perspective is in line with the neoliberal economic consumerism approach, in which what matters is that consumers have easy access to different choices at the cheapest price (Wilson, 2013).

However, in microcredit markets the outcomes are not always positive. By increasing information asymmetries between lenders and borrowers, competition may be detrimental for the poorest clients as providers may tend to concentrate in the safer and less poor clients (McIntosh and Wydick, 2005). Intense competition among financial providers may also lead to collusion and oligopolistic practices that allow high interest rates, as observed in Ecuador, Mexico and the Philippines (Karnani, 2011); and it can reduce the selection standards, weaken the relationships with the clients (Armendariz and Morduch, 2010), and facilitate multiple borrowing and client default (Assefa et al., 2013).

These are some of the elements identified in the delinquency crises that have occurred in some of the most important microfinance markets. Chen et al. (2010) mention market competition and multiple borrowing, MFIs' outstretched systems and controls, and the erosion of the lending discipline as primary causes for the crises in Bosnia-Herzegovina, Nicaragua, Morocco and Pakistan. D'Espallier et al. (2015) explore the perils of MFIs' focus on growth as the pressure put on the financial and operational skills of the organizations can lead to the erosion of important mechanisms in the traditional microcredit programs success, namely the decentralized decision process and the proximity between credit officers and clients. Finally, based on quantitative data from several countries, Krauss et al. (2012) mention market penetration as one of the roots of the overindebtedness crises. By contrast, Yigma (2015) using a dataset of 953 MFIs concludes that higher growth does not lead to increased default risk, inversely it improves portfolio quality.

In the analysis of the crises, and in the response to them, the association between delinquency rates and clients' overindebtedness assumed particular relevance and reinforced the attention given by practitioners to portfolio quality. The maintenance of a low PAR $_{30}$ (Portfolio at Risk at 30 days) is seen by many practitioners as sufficient to ensure that the clients are not overindebted, but there is no direct correlation between non-repayment of the loans and overindebtedness (Schicks, 2013; Gonzalez, 2008; Guérin et al., 2013).

The quest for growth in order to achieve financial sustainability, and the strong belief in portfolio quality as guarantor of a healthy market, are translated into the operational targets and incentive schemes set by the MFIs managers for their loan officers. These are based on portfolio size, growth and quality criteria (McKim and Hughart, 2005), and make use of financial indicators as the $\mathrm{PAR}_{30}$, a noticeable sign of the banking logic influence in microfinance. Incentives and training help in aligning loan officers and management interests, minimizing agency costs, and 
guaranteeing a focus on growth while keeping arrears under control. At the end, however, the institutional perspective, being the interest of the MFI (and its owners), prevails.

In contrast with the principles proclaimed by the Smart Campaign, clients seem to come second. The examples of financial fragility found among borrowers, independently of its causes, seem to be undervalued by the MFIs as long as these clients keep repaying their microcredit loans (Schicks, 2014; Guérin et al., 2013; Morvant-Roux et al., 2015). It is therefore crucial that MFIs do not forget to monitor client satisfaction, and take up the task of raising client awareness of their rights and responsibilities (Ghate, 2007).

In April 2014, the Microfinance CEO Working Group ${ }^{6}$ prioritized the following as self-regulation mechanisms to be adopted by lenders in order to mitigate the risk of overindebtedness: regular reporting to a universal credit bureau ${ }^{7}$ strengthening of screening processes to be able to effectively evaluate the candidate's level of indebtedness; and monitoring carefully areas of high competition (Firth, 2014).

Among these priorities, credit reporting has recently received much attention from microfinance practitioners and policymakers in a context of high growth, competition and increased risk of cross-borrowing. In order to be effective, all the lenders involved in a given market are meant to regularly report to the credit bureau (Chen et al. 2010). However, credit bureaus depict only a partial image of a country's financial sector as they do not include the vast majority of informal financial providers, an important source of credit for example in the Dominican context.

The over-indebtedness prevention mechanisms enlisted above can be seen as a form of selfregulation. Gugerty (2008) describes self-regulation as collective action aiming to shape or constrain organizational behaviour through standards and rules of conduct set by an industry-level organization (as the Smart Campaign). Since these rules do not have the force of law, the implementation of this collective action presents critical challenges for the participants. Rozas (2014), when talking about the attempt by MFIN to establish a code of conduct for MFIs, describes some of these challenges for the microfinance sector. Gugerty (2008) based on the institutional theory suggests that effective self-regulation requires two conditions: clear standards for behaviour and credible enforcement mechanisms.

In section 4, we will show that both conditions fail in the microfinance sector in a context of high competition and growth oriented institutions. Our study will point out that the Dominican Republic case illustrates that high-standard microfinance service provision within a regulated, expanding industry, with low portfolio at risk and widely used credit bureaus, does not necessarily bring about positive social outcomes for the clients.

\section{The Dominican Republic experience}

\footnotetext{
${ }^{6}$ The CEO Working Group integrates the leaders of ten international institutions promoting microfinance: Accion, BRAC, CARE, FINCA International, Freedom from Hunger, Grameen Foundation, Opportunity International, Pro Mujer, VisionFund International and Women's World Banking, http://microfinanceceoworkinggroup.org/ (access on 28/02/2015).

${ }^{7}$ Credit bureaus are institutions, public or private, which gather and give out information on the creditworthiness of individual borrowers as well as enterprises (Pearson, 2008).
} 


\subsection{Research methodology}

The research builds on qualitative fieldwork developed in the two largest cities, Santo Domingo and Santiago de los Caballeros, where most clients and institutions are concentrated, and competition is high. The six participating MFIs include the market leaders (Banco Ademi and Banco Adopem), a NGO that was under a transformation process to become a Bank (FONDESA), a cooperative (ASPIRE) and two NGOs (FDD and FIME). ${ }^{8}$

Over the three years (2012-2015) of the Microfinance in Crisis research project, four field visits of one week to three months were carried out, allowing an in-depth contact with the main players in the market (clients, loan officers, MFIs' managers, informal credit providers, local consultants and other actors), and a comprehensive analysis of the particular interactions between supply and demand.

The heterogeneity of situations associated with microfinance markets, particularly when addressing questions as complex as client overindebtedness, upholds the option to use qualitative methodologies. These are best suited to disentangle and analyze cognitive and social processes that underlie the observed effects (i.e., how a given intervention triggers effects ultimately resulting in an observed outcome).

Qualitative methodologies draw on a broad range of methods. This paper is based on semistructured interviews performed with a wide set of actors aiming at comparing and contrasting insights from different perspectives (triangulation), and uncovering the heterogeneity of the individual situations. We interviewed 45 MFI clients, 14 non-clients, 4 head managers, 10 branch managers, loan officers (visit of 16 branches, representing more than 100 loan officers and 50,000 active clients), and other main actors in the field (including 4 informal lenders). Furthermore, the work also included the observation of 12 loan officers' daily work; the participation at 5 staff training sessions; and the revision of MFIs' internal documentation. The loan officers interviewed, and accompanied in their daily work, had different levels of experience and were working in various microcredit programs.

Clients were chosen to ensure diversity of repayment performances, portfolio of activities and neighbourhoods. It is important to stress that we took into account the appreciation of the client by the loan officer in charge of the specific area where we were conducting the interviews. We asked them to identify the 'good' borrowers and the 'bad', meaning late. This allowed us to capture the gap between the information gathered by the loan officers and our own information after interviewing the clients. Non-clients were selected randomly in the same neighbourhoods. The clients and non-clients interview guides included questions about family composition, main life cycle events, and evolution of employment status/portfolio of activities, including job migration. We also included questions about financial practices: savings, credit sources, outstanding debt level, and weekly repayments. We gave particular attention to 'repayment hierarchies': which credit providers come first in the repayment priorities, relationship with and perception of each specific credit provider, etc. Finally, in order to uncover punctual shocks and structural factors that may affect repayment behaviour and lead to potential sacrifices, an ex-post

\footnotetext{
${ }^{8}$ FIME is a subsidiary of VisionFund International and has recently changed its name to VisionFund Republica Dominicana.
} 
assessment of repayment strategies was performed, focusing on concrete examples and avoiding general answers.

Following Van den Berg (2005), contextualizing data collection is an important aspect of the qualitative approach. Clients, as well as loan officers, may use a different discourse depending on the interview location. We, therefore, insisted on doing the interviews like 'informal' discussions, meeting the interviewees at home instead of the MFI branch office. Triangulation of information (as mentioned previously) was also a main concern along our data collection process. It was achieved through daily meetings among team members, which allowed comparing observations from different researchers, and by interviewing a large set of actors.

\subsection{The Microfinance sector}

The Dominican Republic is classified as a middle-income country, and is the largest economy in Central America and the Caribbean. However, infrastructures are still highly inadequate; poverty is higher $(41 \%, 2013)$ than in $2000(32 \%) ;{ }^{9}$ and a significant part of the economically active population is self-employed ( $40 \%$ in April 2014). ${ }^{10}$

As far as the financial supply is concerned, 12 MFIs reported to the Mix Market in 2013 while the national microfinance network, REDOMIF, had 22 members serving 387,192 clients $(60.3 \%$ women), and a loan portfolio of 619,04 million US\$. ${ }^{11}$ The largest MFIs, Banco Ademi and Banco Adopem are regulated financial institutions, ${ }^{12}$ and are supervised by the Dominican Republic Central Bank. In 2014, the definitive version of the Microcredit Regulation was approved. ${ }^{13}$

Table 1 - Microfinance Sector in the Dominican Republic

\begin{tabular}{|c|c|c|c|c|c|c|}
\hline MFI & $\begin{array}{c}\text { Report } \\
\text { Date }\end{array}$ & $\begin{array}{c}\text { Nr. Borrowers } \\
(\text { Female })\end{array}$ & Loans (USD) & $\begin{array}{c}\text { Nr. } \\
\text { Depositors }\end{array}$ & $\begin{array}{c}\text { Deposits } \\
\text { (USD) }\end{array}$ & $\begin{array}{c}\text { PAR }_{30} \\
(1)\end{array}$ \\
\hline Banco ADEMI & Jun15 & n.a. (50\%) & $270,227,542$ & 230,391 & $241,196,213$ & $1,5 \%$ \\
\hline Banco ADOPEM & Jun15 & $\begin{array}{c}207,218 \\
(70.7 \%)\end{array}$ & $100,855,481$ & 330,863 & $52,808,838$ & $3.5 \%$ \\
\hline ALNAP & 2014 & $\begin{array}{c}29,799 \\
(38.6 \%)\end{array}$ & $328,955,819$ & n.a. & $419,933,432$ & $2.5 \%$ \\
\hline BANFONDESA & 2014 & 69,337 & $54,911,992$ & - & - & n.a. \\
\hline COOP-ASPIRE & 2014 & $24,033(70.4 \%)$ & $13,781,351$ & 32,395 & $9,445,528$ & $4.2 \%$ \\
\hline ECLOF DOM & 2014 & $\begin{array}{c}17,524 \\
(81,5 \%)\end{array}$ & $6,365,482$ & - & - & $2.3 \%$ \\
\hline FDD & 2014 & $\begin{array}{c}15,712 \\
(57.2 \%)\end{array}$ & $5,087,359$ & - & - & $0.1 \%$ \\
\hline F. Esperanza & 2014 & $10,023(92 \%)$ & $3,469,691$ & - & & - \\
\hline
\end{tabular}

\footnotetext{
${ }^{9}$ World DataBank - World Development Indicators: Poverty headcount ratio at national poverty line (\% of population) available at http://databank.worldbank.org/

${ }^{10} \mathrm{http}$ ://www.bancentral.gov.do/estadisticas economicas/mercado trabajo/ (access 04/12/2014).

11 http://www.mixmarket.org/mfi/country/Dominican\%20Republic; http://www.redomif.org.do/ (access 07/09/2015)

12 They both started as NGOs and turned into banks in 1997 and 2004, respectively. Other institutions are following this transformation pattern is: ASPIRE became a cooperative in 2013 and FONDESA, the third biggest MFI, is in the process of becoming a credit and savings bank.

${ }^{13}$ Document available at:

http://www.bancentral.gov.do/normativa/normas vigentes/financieros/Segunda Resoluci\%C3\%B3n Junta Monetari a 14 agosto 2014 aprueba versi $\%$ C3\%B3n definitiva Reglamento Microcr\%C3\%A9ditos.pdf (access 20/06/15)
} 


\begin{tabular}{|c|c|c|c|c|c|c|}
\hline $\begin{array}{c}\text { Vision Fund } \\
\text { DOM }\end{array}$ & 2014 & $5,297(60.4 \%)$ & $2,279,968$ & - & - & $7.2 \%$ \\
\hline $\begin{array}{c}\text { Credito Amigo } \\
\text { (BHD) }\end{array}$ & 2013 & $5,912(45.5 \%)$ & $9,895,322$ & n.a. & $1,951,669$ & $4.1 \%$ \\
\hline CDD & 2013 & $4,207(70 \%)$ & $1,644,649$ & n.a. & 43,018 & $10.4 \%$ \\
\hline MUDE DOM & 2013 & 4,420 & 896,896 & - & - & n.a. \\
\hline
\end{tabular}

Sources: Mix Market and REDOMIF

Notes: n.a. - not available (1) Data on 30/06/2014

The microfinance landscape is, however, much larger and diversified. The government participates directly in the market through public credit programs (Promipyme and Banca Solidaria), and similarly commercial banks like BHD and ScotiaBank have set up separate microcredit units - Crédito Amigo and Scotia Soluciones, respectively. There are various other formal and semi-formal financial providers, including local cooperatives, and many small to medium sized companies. They usually offer credit at a higher interest rate than MFIs, ${ }^{14}$ and have shorter terms and frequent instalments.

Beyond semi-formal and formal credit providers, various recent studies have shown the relevance of informal financial landscapes to understand how people perceive and use different formal financial services such as microcredit (Morvant, 2006; Collins et al., 2009; Guérin et al., 2011a). The informal sector is highly developed in the Dominican Republic. ${ }^{15}$ Loans issued through social networks (family and friends), on one side, and private lenders, on the other, represented the two main sources of credit, for the bottom $40 \%$ of the population in 2014 , according to the Global Financial Inclusion Index. ${ }^{16}$ Lending money is perceived as a lucrative activity and some microcredit officers start their own moneylending businesses (after leaving their MFIs), while some microcredit borrowers are themselves moneylenders. The informal sector also includes pawnbrokers, ROSCAs, and credit purchases for durable goods.

MFIs are, therefore, part of a highly dynamic and interrelated financial landscape, in which formal and informal sharing information mechanisms are an important feature. There are two private credit bureaus, Datacred and Transunion, which are widely used, including by some informal lenders who usually report to one of the bureaus.

For the largest MFIs at least, lending policies and procedures adhere to international 'best practices'. This includes sophisticated techniques for assessing client indebtedness, repayment capacities and willingness to repay (Afonso, 2013). This cautious sector management has kept portfolio at risk under control $\left(\mathrm{PAR}_{30}\right.$ was $5 \%$ in 2013). ${ }^{17}$

Using Mix Market data for 2008, Gonzalez (2010) found a penetration rate of microfinance in the total population of the Dominican Republic of below 4\% which compared to $25 \%$ in Bangladesh,

\footnotetext{
${ }^{14}$ Contact with clients and some moneylenders indicated a common interest rate of $20 \%$ /month for informal loans, though we did find lower rates (one private moneylender interviewed applied an average of $8 \% / \mathrm{month}$ ), while one of the largest microcredit banks charged between 3 and 4.6\%/month for the different business loans.

${ }^{15}$ The estimated number of moneylenders in the country appears to be between 8000 and 11500 (Gonzalez and Servet, 2014)

${ }^{16} \mathrm{http}$ ://datatopics.worldbank.org/financialinclusion/country/dominican-republic (access 24/05/2015)

17 http://www.redcamif.org/index.php/es/calidad-de-cartera.html (access 19/05/2016). The data from REDCAMIF shows that $\mathrm{PAR}_{30}$ has been deteriorating since December 2013, growing from 5\% to $7.4 \%$ at the end of 2015 .
} 
and to higher rates in other Latin American countries, such as Nicaragua (11\%), Peru (10\%) and Bolivia (9\%). ${ }^{18}$

Nonetheless, this picture seems to be changing. In the MIMOSA (Microfinance Index on Market Outreach and Saturation) report based on 2014 data, the Dominican Republic market is classified as a normal, approaching saturation market (score 3), which compares with a score 2, normal in 2011 (Javoy and Rozas, 2015). Likewise, the Global Findex data for 2014 shows an impressive increase in the number of adults with formal bank accounts (from 38\% in 2011 to 54\%), and an also relevant growth of the percentage of adults that had obtained credit from formal financial providers (13.9\% in 2011 to $18.2 \%$ ); with more than half of the respondents having borrowed some money in the previous year (both from formal and informal sources). ${ }^{19}$

Thus, while the country's microfinance market is still maturing with close to 1,4 million potential clients without or with limited access to formal financial services (most of them located in rural and marginalized areas), ${ }^{20}$ in some sections of the largest cities, competition is fierce (as recognized by some of the MFIs managers). These are densely populated areas where most people are considered to be poor and self-employment is high. One top manager explained that competition was especially strong for a particular segment of the population: entrepreneurs with small but organized businesses requesting loans of around US\$1,000 (the 'good and safe' clients).

In our field work, developed in these competitive areas, we found that a part of the clients interviewed were in a financially vulnerable situation (Figure 1). We used various indicators (debt/income ratio, short and long term sacrifices to repay, no perspective of exit debt) to assess the indebtedness level of the 45 MFI clients we interviewed.

Figure 1 - MFI Clients Indebtedness Level

\footnotetext{
${ }^{18}$ Gonzalez (2010) concludes that rates over $10 \%$ were likely to deteriorate the portfolio quality of the MFIs.

${ }^{19} \mathrm{http}$ ://datatopics.worldbank.org/financialinclusion/country/dominican-republic (access 04/04/16). Adults include all population with 15 or more years and credit from formal institutions refers to borrowings from a bank, credit union, microfinance institution, or another financial institution such as a cooperative.

20 http://www.fomin.org/en-us/Home/News/PressReleases/ArtMID/3819/ArticleID/49/The-MIF-works-to-improveaccess-to-microfinance-services-in-rural-areas-of-the-Dominican-Republic.aspx (access 23/09/15)
} 


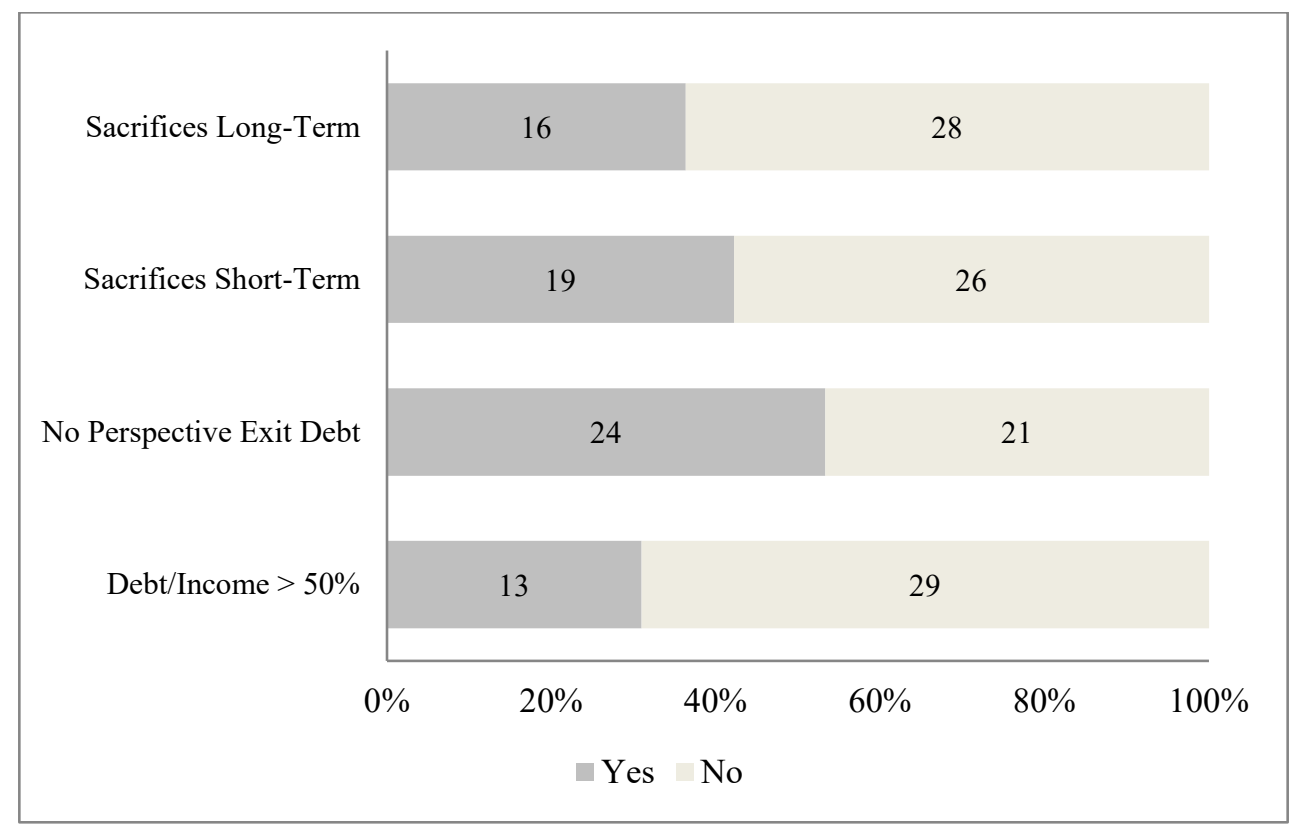

Source: Own construction

Notes:

The data on "sacrifices long-term", "sacrifices short-term" and "no perspective of exit debt" correspond to the subjective perception of the interviewed clients on the sacrifices made to be able to keep repaying their loans. Thus, sacrifices long-term reflect what the clients are compromising in the future (for instance, investments in housing or education); sacrifices short-term relate to cuts on daily consumption (food, communications, etc.); and the perspective of exit from debt refers to the ability to totally repay the active loans in the short-term.

The ratio debt/income data was also collected during the interviews. It corresponds to the part of the household monthly income that needs to be allocated to debt (installments) repayment.

For eight households, the debt/income ratio was higher than $67 \%$. These more indebted households included, very interestingly, four clients that were introduced by the respective loan officers as 'regular' or 'good' clients who always or often repaid on time. In the interviews, they openly talked about how they struggled to repay their loans. One told us that he was always struggling, and that he had no way out of the debt ("siempre vivo con apuro y no hay forma de pararlo"). A mother told us she was giving water and sugar to her baby instead of milk whenever she was running late with repayments. Nonetheless, as most of them stressed, it is better to make sacrifices, such as only eating rice and bananas, than to lose the asset of being a good payer. These results are in line with the findings of Schicks (2014) in Ghana, albeit a different context, and seem to indicate a prevalence of market dynamics over client protection measures.

\section{Best practices and self-regulation in "practice"}

The success of initial microcredit programs has been associated with the innovation of group lending methodology but, for several reasons, the evolution of the sector has been accompanied by a preference for individual loans (Ledgwerwood and Gibson, 2013). This is a trend also verified in the Dominican Republic. ${ }^{21}$ The loans are usually individual, which boosts the impact

${ }^{21}$ REDOMIF reports only $12.1 \%$ of the loan portfolio of their members corresponded to group loans in 30/06/2014. http://redomif.org.do/data/uploads/revista microfinanzas de centroamerica y del caribe edicion 21 junio 2014 web.pdf (access 08/09/2015) 
of the institutional screening procedures, and more concretely the credit officers' practices, in the success of the loans and in the management of overindebtedness risks.

A proper selection of clients means having in place an evaluation process that combines formal and informal information sources, including the credit bureau (Afonso, 2013). However, the level of informality prevailing both at the labor and financial markets in the Dominican Republic (Ortiz et al., 2014) introduces operational constraints that weaken the selection process. Loan officers have to depend on informal sources to complement the data obtained from the credit bureau but, needless to say, collecting data from informal sources is a difficult task: it is not easy to meet the people, information is not error free, and the process is time consuming. Finally, it implies building close relationships with clients, and may bring additional risks as highlighted in other contexts as shown by Morvant-Roux \& Roesch (2015) in urban and peri-urban settings of Morocco.

\subsection{Pressure on loan officers}

In the field experience what was observed was that loan officers (in general) have very tight schedules with a diversity of tasks that prevent a more thorough evaluation of the clients. The time dedicated, and the level of priority given by the loan officers to each task, is highly dependent on the incentive schemes defined by the MFIs' management, and on the daily directives provided by the branch managers. Under the pressure of growth and competition, the accomplishment of monthly and quarterly goals becomes a much more present concern at branch level than the rigour of the screening process, and this was common to all MFIs.

At one of the MFIs, interviews with loan officers and observation at the branch level revealed that the goals set by top managers were in general considered ambitious; the rewards for attaining them had an important weight in the loan officers' income and their career prospects; and, likewise, the regular non-achievement of the targets was associated with dismissal. The monthly goals were defined in terms of number and amount of loans, and arrears. In the first six months of 2013, goal achievement by the institution's loan officers was irregular but the negative incentive (dismissal) was not confirmed. Nevertheless, as shown by Afonso (2013) the pressure on most loan officers was evident, even if there was flexibility when assessing the performance ${ }^{22}$.

This pressure also translates into the effort to renew loans of existing clients or to attract new clients, creating the conditions for weakened evaluation procedures. In such a competitive market, with very strong information asymmetries, it is easier to grow through existing clients. We found that many MFIs have a policy to refinance clients when they reach around three quarters of the loan and have been repaying regularly, creating a permanent debt-relationship. ${ }^{23}$ Some of the interviewed loan officers told us that they try to stimulate demand by "creating the necessities"; if they see that a 'good' client is not considering applying for a new loan. Using the information

\footnotetext{
${ }^{22}$ Data on goals compliance in the previous 6 months (for the 288 loan officers with portfolio assigned for at least 6 months at 30/06/2013) showed that half of the loan officers did not manage to reach the arrears goal in at least 3 months ( $65 \%$ for the target number of loans, and $41 \%$ for the loans amount goal). The data was obtained from the information system of one of the largest MFIs (Afonso, 2013).

${ }^{23}$ It is common policy for MFIs to renew loans, but some of them try to restrict this practice not allowing there structuring or consolidation of defaulting loans.
} 
collected in the home visit to the client, they suggest possible ways to invest the new credit, such as buying a computer for the children, renovating a room in the house or investing in the business.

The effort to achieve the arrears goals was reflected in the time spent on recovery tasks, and in the amount of pressure put on the clients to repay, both in terms of the number of contacts close to the repayment date and the arguments used to 'convince' the client. Some loan officers try to use clients' compassion towards the potential loan officer dismissal if he/she does not meet the targets. One of the loan officers suggested to a client to take up a loan from a moneylender in order to repay the microcredit instalment before the end of the month (i.e. before arrears affected $\left.\mathrm{PAR}_{30}\right)$.

From a different perspective, the focus on arrears as the alert signal for overindebtedness leads to less rigour put into the evaluation process of renewal loans, as long as the client is repaying on time (as reported by several branch managers and loan officers from different MFIs).

Thus, our field observations, both at client and credit officers' levels, indicate that the combination of growth and portfolio quality imperatives, in a context of high competition, can push credit officers to indulge in practices that are not in the clients' best interest.

\subsection{Lender uses and Borrower perceptions of the Credit Bureau}

Credit bureaus are seen as one of the most effective means to protect clients, and they are widely used in the Dominican Republic. The data available allows for the evaluation of the client's indebtedness level, and the identification of cross-borrowing practices. This is particularly relevant since the relation between multiple borrowing and overindebtedness has been confirmed in several empirical studies conducted in Bolivia (Vogelgesang, 2003), the Philippines (Diaz and Ledesma, 2011) and Cambodia (Dannet, 2013).

The maximum number of active loans that a candidate may have registered at the credit bureau, in order to be eligible for a microcredit loan, is an interesting proxy for the offer and competition of the microfinance market. The six MFIs had various policies in this respect. Some have fixed the maximum at three loans, while for others the number is flexible and depends on case-by-case evaluations. However, whatever the criteria used, this analysis is insufficient in the context of the Dominican financial landscape. The relevance of informal financial sources (illustrated in the latest results of the Global Findex), and the fact that only a very small part of these lenders reports to one of the credit bureaus (González and Servet, 2014), makes it easy to find clients with five or more active loans, as indeed happened with some of the clients interviewed ( 8 cases in our sample).

Moreover, the credit bureau information is not immediately updated (it can take up to a month). If a client applies for loans from more than one MFI simultaneously, this situation will not be visible in the bureau consultation made during the evaluation process, and the client might then obtain more than one loan at the same time. Such cases are easy to detect as we found in our sample. For instance, one of the clients interviewed had successfully applied for credit simultaneously from three MFIs for 75,000, 75,000 and 50,000 DOP, obtaining a total of 200,000 DOP. 
The issues related to the credit bureau do not only relate to insufficient coverage. In some MFI branches, credit bureaus are used, not only to assess the level of debt of their potential clients, but also as a source of information for 'stealing' clients. Clients of other MFIs are offered additional funding if they take up a loan with the MFI that repays the previous loan(s) with other institution(s). This is claimed to be a competitive strategy, whereby loan officers try to recruit new clients. It carries, however, some dangers by increasing the indebtedness level of the clients. Besides the larger amount of the new loan, there is no guarantee that the client will repay the previous credit as it was the case of one of the clients interviewed.

The access to MFI loans by people previously excluded from the formal financial markets allows them to start a credit history in the credit bureau, and 'opens a door' to future opportunities. However, this argument can be quite dangerous for some clients. If a borrower/potential client is known to have credit, and the information from the bureau is positive, this potential client will most likely be contacted by formal and informal lenders offering a wide variety of products, and sometimes making use of marketing techniques that may be considered as aggressive. This was the case of one of the clients interviewed in Santo Domingo. He did not have debt previously but once he got the first formal credit, a credit card from a Bank, he was repeatedly approached by other institutions and ended up with five different credit cards (all regularly used) and two loans, from a cooperative and a microfinance institution. He was, unsurprisingly, struggling to repay all these debts on time.

The credit bureau has an even stronger role in repayment enforcement, acting as an effective deterrent of strategic default situations. The consequences associated with being blacklisted in the credit bureau go beyond access to new loans. It affects also the possibilities of having a bank account, making utilities contracts and even access formal jobs and visas to travel. Thus, building a good credit score at the credit bureau, to ensure present and future needs, is an 'easy' argument used by the loan officers when promoting the MFI's credit products or when recovering loans. The field work has shown that loan officers do use it persistently.

Equally, the power of the argument is reinforced by the perception the clients have on the credit bureau ("el diablo", for some), and on their financial needs. There are psychological motives (overconfidence, time bias, lack of self-discipline), as well as social factors (social mobility aspirations, consumerism, social norms related to debt, peer pressure), that can lead poor people to increase their debt beyond their true capacity to repay as highlighted by various qualitative case studies from India, Mexico and Madagascar in Guérin et al. (2013) and in Ghana by Schicks (2013). The awareness by clients and non-clients of the existence of the credit bureau (and the negative consequences of defaulting) is among these factors, and induces practices of cross-debt and juggling strategies so as to maintain creditworthiness with formal financial institutions, even when repaying already implies some sort of sacrifice or extra effort as shown by Guérin et al. in rural south India (2011)

\section{Conclusions}

Several scholars have pointed out that the commercial microfinance industry has a fundamental problem with recurring crises of overindebtedness (D'Espallier et al., 2015). The Dominican Republic case study shows evidence that current weapon of choice, self-regulation, is ineffective. Actually, while microcredit markets may bring valuable social outcomes, competition, efficiency 
and self-governance translate into unhealthy growth and market saturation in some areas, affecting clients' well-being.

Similarly to what has happened in other areas of development, the attention given to selfregulation mechanisms in the microfinance sector has been a reaction to the delinquency crises in the sector, and the bad publicity associated with them (Loyd and De Las Casas, 2006). However, the two conditions for successful self-regulation identified by Gugerty (2008), clear standards and enforcement mechanisms, are not met in the Dominican Republic. The main MFIs adhere to international principles and 'best practices' concerning overindebtedness prevention that are broadly defined by the Smart Campaign but each institution defines and implements its own mechanisms as there is no set of policies and procedures defined collectively (for instance at the national microfinance network level), and there are no external enforcement mechanisms. Microfinance markets should, therefore, be carefully organized.

The Dominican case draws attention to the need for the sector as a whole to reflect deeply on the principles orienting the commercialization movement, namely the focus on growth and financial sustainability, and its effects on competition. This reflection should also include an evaluation of the self-regulation mechanisms in place, introducing the necessary changes to make them effective. Considering the operational constraints and the pressure exerted on the loan officers, it will be crucial that among these changes MFIs re-evaluate their growth objectives and strategies, as well as the incentive schemes and signals conveyed to loan officers in the more saturated areas.

Furthermore, highlighting the idea that clients' overindebtedness may exist independently of their repayment performance, it will also be important to look beyond the portfolio quality indicators, and consider strategies to minimize borrowers' risk factors. While financial literacy is often mentioned as the other magic bullet to prevent overindebtedness, we consider that changing the borrowers' behaviour is not enough, and we argue that these measures should come with a new paradigmatic shift within the sector itself.

In the Dominican Republic, there is a good opportunity for MFIs to change the present 'picture'. The new regulation on financial agents opens possibilities for MFIs to extend their services to more remote and underserved areas, minimizing the obstacles associated with higher transaction costs in these areas, and alleviating the competitive pressure in the more saturated urban areas. Although this is a new process that will imply changes and adjustments by the institutions, it is a good example of how public intervention can influence MFI behaviour and complement selfregulation mechanisms.

Emphasizing the idea that microfinance programs are implemented in a complex context in which demand, supply and environmental factors interact, it will be important in future research to further explore the role of regulation and public intervention in microfinance, and its interaction with the self-regulation mechanisms implemented within the sector.

\section{References}

Afonso J. 2013. Loan officers and preventing overindebtedness - the case of Banco ADOPEM. Research and Policy Brief 8. Microfinance in Crisis: Paris

Assefa E, Hermes N, Meesters A. 2013. Competition and the performance of microfinance institutions. Applied Financial Economics 23 (9): 767 - 782

Armendáriz B, Morduch J. 2010. The Economics of Microfinance, $2^{\text {nd }}$ ed. MIT Press: Cambridge 
Banarjee A, Karlan D, Zinman J. 2015. Six Randomized Evaluations of Microcredit: Introduction and Further Steps. American Economic Journal: Applied Economics 7(1): 1-21

Banks N, Hulme D. 2014. New development alternatives or business as usual with a new face? The transformative potential of new actors and alliances in development. Third World Quarterly, 35 (1) : 181-195, DOI: 10.1080/01436597.2014.868997

Chen G, Rasmussen S, Reille X. 2010. Growth and Vulnerabilities in Microfinance. CGAP Focus Note 61,

Collins D, Morduch J, Rutherford S, Ruthven O. 2009. Portfolios of the Poor - How the World's Poor Live on \$2 a Day. Princeton University Press: Princeton

D'Espallier B, Labie M, Louis P. 2015. Microcredit Crises and Unstainable Growth: a Management Perspective. In The Crises of Microcredit, Guérin I, Labie M, Servet JM. (eds); Zed Books: London

Dannet L. 2013. Study on the Drivers of Over-Indebtedness of Microfinance Borrowers in Cambodia: An In-depth Investigation of Saturated Areas. Final Report, Cambodia Institute of Development Study

Diaz J, Ledesma J. 2011. A Closer Look at Multiple Borrowing in the Philippines. MicroSave Briefing Note $\mathbf{1 1 4}$

Duvendack M, Palmer-Jones R, Copestake J, Hooper L, Loke Y, Rao N. 2011. What is the evidence of the impact of microfinance on the well-being of poor people? EPPI Centre, Social Science Research Unit, Institute of Education, University of London: London

Firth B. 2014. Over-Indebtedness: A Risk Management Approach. Microfinance CEO Working Group: Washington DC

Forster CS. 2012. Codes of Conduct and the Role of Microfinance Associations in Client Protection. The SEEP Network: Washington DC

Gonzalez A. 2008. Microfinance, Incentives to Repay, and Overindebtedness: Evidence from a Household Survey in Bolivia. PhD Dissertation, The Ohio State University

Gonzalez A. 2010. Is Microfinance Growing Too Fast? Mix Market Data Brief 5

González C, Servet J M. 2014. Pourquoi le microcrédit en République Dominicaine a échappé à la crise. Working Document. Microfinance in Crisis: Paris

Ghate P. 2007.Consumer protection in Indian microfinance - Lessons from Andhra Pradesh and the microfinance bill. Economic and Political Weekly 42 (13): 1176 - 1184

Guérin I, Roesch M, Venkatasubramanian, Santosh K. 2011. The Social Meaning of Overindebtedness and Creditworthiness in the context of Poor Rural South India Households (Tamil Nadu). RUME Working Papers Serie 2011-1. IRD: Paris

Guérin I, Morvant-Roux S, Servet J M. 2011a. Understanding the Diversity and Complexity of Demand for Microfinance Services: Lessons from Informal Services. In The Handbook of Microfinance. Armendáriz B, Labie M. (eds); World Scientific: Singapore

Guérin I, Morvant-Roux S, Villareal M. 2013. Introduction. In Microfinance, Debt and OverIndebtedness: Juggling with Money. Guérin I, Morvant-Roux S, Villareal M. (eds); Routledge: London

Guérin I, Labie M, Servet JM. 2015. Introduction. In The Crises of Microcredit. Guérin I, Labie M, Servet JM. (eds); Zed Books: London

Gugerty MK. 2008. The Effectiveness of NGO Self-Regulation: Theory and Evidence from Africa. Public Administration and Development 28: 105 - 118

International Finance Corporation (IFC). 2013. Progress in Responsible Financial Inclusion Global Mapping Report and Selected Case Studies. IFC: Washington DC 
Intellecap. 2009. Inverting the Pyramid - Indian Microfinance Coming of Age. Intellecap: Hyderabad

Javoy E, Rozas D. 2015. MIMOSA - Microfinance Index of Market Outreach and Saturation, Fondation Planet Finance: Paris

Loyd R, De Las Casas L. 2006. NGO self-regulation: enforcing and balancing accountability. One World Trust: London

Karnani A. 2011. Fighting Poverty Together: Rethinking Strategies for Business, Governments, and Civil Society to reduce Poverty. Palgrave Macmillan: New York

Kent D, Dacin M.T. 2013. Bankers at the gate: Microfinance and the high cost of borrowed logics. Journal of Business Venturing 28: 759 - 773

Krauss A, Lontzek L, Meyer J, Frommelt M. 2012. Lack of access or crowded markets? Towards a better understanding of microfinance market penetration. Working Paper. University of Zurich Lascelles D, Mendelson S. 2012. Microfinance Banana Skins 2012: Staying Relevant. CSFI: New York

Lascelles D, Mendelson S, Rozas D. 2014. Microfinance Banana Skins 2014: Facing Reality, CSFI: New York

Ledgerwood J, Gibson A.2013. The Evolving Financial Landscape. In The New Microfinance Handbook: A Financial Market System Perspective. Ledgerwood J. (ed.); The World Bank: Washington DC

McIntosh C, Wydick B. 2005. Competition and Microfinance. Journal of Development Economics 78: 271 - 298

McKim A, Hughart M. 2005. Staff Incentive Schemes in Practice: Findings from a Global Survey of Microfinance Institutions. Microfinance Network

Morvant S. 2006. Processus d'appropriation des dispositifs de microfinance: un exemple en milieu rural mexicain. Thèse de doctorat en sciences économiques. Université Lumière Lyon 2

Morvant-Roux S, Roesch M. 2015. The social credibility of microcredit in Morocco after the default crisis. In The Crises of Microcredit. Guérin I, Labie M, Servet J M. (eds); Zed Books: London

Morvant-Roux S, Afonso J, Forcella D, Guérin I. 2015. How good repayment performances can harm borrowers: evidence from Dominican Republic. In The Crises of Microcredit. Guérin I, Labie M, Servet J M. (eds); Zed Books: London

Ortiz M, Cabal M, Mena R. 2014. Micro, pequeñas y medianas empresas en la Republica Dominicana 2013. FondoMicro: Santo Domingo

Pearson R S. 2008. Relationship Banking in a Competitive Environment with and without Information Sharing: the Importance of Credit Bureaus in Microfinance, PhD Dissertation, The Ohio State University

ResponsAbility. 2014. Microfinance Market Outlook 2015 - Growth driven by vast potential market. ResponsAbility: Zurich

Rozas D. 2013. What's Next: Another Repayment Crisis? http://www.financialaccess.org/blog/2013/02/what $\%$ E2\%80\%99s-next-another-repaymentcrisis (access on 20/05/2015)

Rozas D. 2014. Microfinance self-regulation in India becomes official. http://www.danielrozas.com/2014/06/24/microfinance-self-regulation-in-india-becomesofficial/ (access on 19/06/15)

Schicks J, Rosenberg R. 2011. Too Much Microcredit? A Survey of the Evidence on OverIndebtedness", CGAP Occasional Paper 19, CGAP: Washington DC 
Schicks J. 2013. The Definition and Causes of Microfinance Over-Indebtedness: a Customer Protection Point of View. Oxford Development Studies 41 suppl.: 95 - 116

Schicks J. 2014. Over-Indebtedness in Microfinance - An Empirical Analysis of Related Factors on the Borrower Level", World Development 54: 301 - 324

Sewell W. H. 1996. Historical Events as Transformation of Structures: Inventing Revolution at the Bastille. Theory and Society 25 (6): 841 - 881

Smart Campaign. 2013. Avoidance of Overindebtedness: Guidelines for Financial and NonFinancial Evaluation. http://www.smartcampaign.org/storage/documents/avoidance.pdf (access 15/07/2013)

Soederberg S. 2013. Universalising Financial Inclusion and the Securitisation of Development. Third World Quarterly 34 (4):593 - 612

Thornton P H, Ocasio W. 2008. Institutional Logics. In The SAGE Handbook of Organizational Institutionalism. Greenwood R, Oliver C, Sahlin K, Suddaby R. (eds); SAGE: London Van den Berg H. 2005. Reanalyzing Qualitative Interviews From Different Angles: The Risk of Decontextualization and Other Problems of Sharing Qualitative Data. Forum Qualitative Sozialforschung / Forum: Qualitative Social Research, 6 (1), Art. 30, http://nbnresolving.de/urn:nbn:de:0114-fqs0501305.

Vogelgesang U. 2003. Microfinance in Times of Crisis: The Effects of Competition, Rising Indebtedness, and Economic Crisis on Repayment Behavior. World Development 31 (12): 2085 $-2114$

Wilson T. 2013. Credit and Over-Indebtedness: Current Context, Regulatory Responses and Future Possibilities. In International Responses to Issues of Credit and Over-Indebtedness in the Wake of Crisis. Wilson T. (ed.); Ashgate: Surrey, UK

Yimga, J. 2015. The Impact of High Microfinance Growth on Loan Portfolio. Journal of International Development (2015). DOI: 10.1002/jid.3144 
